\title{
Police Budgeting: Using Overtime as a Management Tool
}

\author{
Leonard Lira $^{1} \cdot$ Frances Edwards ${ }^{1}$ (D)
}

Accepted: 27 June 2021 / Published online: 29 January 2022

(c) The Author(s), under exclusive licence to Springer Science+Business Media, LLC, part of Springer Nature 2022

\begin{abstract}
Following the death of George Floyd, there were national calls for budget reductions and reforms for police departments. The City of San Jose's Auditor's Office analyzed the police department's budget components to understand what police services were being provided. This case study examined several research questions, such as how police overtime funding is being used to deliver police services, and whether the use of overtime is the most efficient method of services delivery. It analyzes why and how overtime allows for equitable and responsive police services, even when the department is short staffed.
\end{abstract}

Keywords Police budgeting $\cdot$ Police overtime $\cdot$ Police services $\cdot$ Fiscal management

\section{Introduction}

Police department budgets are one of the largest expenditures in a city's general fund budget (McCarthy, 2020). After the onset of the COVID-19 pandemic in 2020, governments throughout the world instituted stay-at-home orders to stop disease spread (Taylor, 2021a, b). Commerce was diminished, along with tax revenues for all levels of government. For example, the Pew researchers discovered that US state revenues were down $\$ 46.4$ billion as a result of COVID-19 impacts (Rosewicz et al., 2021), while the Tax Policy Center researchers noted the decline in city revenues (Gordon et al., 2020). As a result, elected officials in the nation's large cities reconsidered their allocation of scarce resources for police services, not only because of COVID-19 driven revenue shortfalls but also because of public outcry against the militarization of police departments and the concomitant cost increases for training (Mummolo, 2018).

Frances Edwards

frances.edwards@sjsu.edu

1 Political Science Department, San Jose State University, One Washington Square, San Jose,

CA 95192-0119, USA 
The San Jose Police Department (SJPD) experienced a 300\% increase in overtime spending between the 2009-2010 and 2019-2020 fiscal years (Rios, 2021), causing the San Jose City Council to request an overtime audit by the city auditor. The management of police budgets, especially overtime, is a public policy problem, which is defined as "an event or condition that produces dissatisfaction" in multiple community members (Guess \& Farnham, 2011, p. 28). It is an "important issue affecting the public in relation to which funds must be spent and/or legislation or regulation may be enacted" (Guess \& Farnham, 2011, p. 23.) Another trigger for the audit was the police department's response to civil unrest generated in San Jose by the death of George Floyd, discussed below. Televised coverage of the San Jose Police interaction with the public (Salonga, 2020) raised the policy problem to the public agenda (Birkand, 1997).

\section{George Floyd and Budgeting}

Police budgeting has been a renewed subject of public debate in 2020-2021 in the United States. The death of George Floyd on May 25, 2020 caused national public outcry over police departments' tactics, training and implementation. Demonstrations and violent protests against police occurred in 140 American cities. The arson, looting and vandalism associated with these events created the highest insured losses related to civil unrest in US history, more than the losses from the Rodney King Riots in Los Angeles in 1992 (Manskar, 2020; Smith, 2020; Taylor, 2021b).

In Minneapolis, where Floyd died, there were calls to defund the police department. Community leaders said, "We are going to dramatically rethink how we approach public safety and emergency response" (Stockman \& Eligon, 2020, p. A15). Police departments around the US have been required to respond to an increased variety of calls for services, including mental health crises, drug overdoses, homeless people's interactions with other community members and domestic dispute calls, events that might be better addressed by unarmed social services staff, like the Cahoots program in Eugene, Oregon (Stockman and Eligon 2020), or the Watsonville, California Crisis Assessment, Respond, Engagement (CARE) program (Perez, 2018). Minneapolis had already taken a step in changing public safety funding patterns by diverting funding from hiring officers to a new use-creating an office for violence prevention. However, one Minneapolis city council member noted concern for "...your constituents that are going to be the victims of crime you can't respond to if you dismantle [the police department] without an alternative" (Stockman \& Eligon, 2020, A15).

\section{Police Budgets}

Police department allocations represent significant portions of most large cities' budgets, as shown in Table 1.

Minneapolis' police budget was cut by $\$ 20$ million for 2020-2021, but rising crime rates over the summer ended enthusiasm for further police department budget cuts from the mayor's office (Ferkenhoff, 2021). Similarly, across the 50 largest US 
Table 1 Police Department Budget as Percent of General Fund, 2020

\begin{tabular}{lll}
\hline City & Police Dept. Budget & $\begin{array}{l}\% \text { of } \\
\text { General } \\
\text { Fund }\end{array}$ \\
\hline New York & \$5.6 billion & 7.7 \\
Los Angeles & \$1.73 billion & 25.5 \\
Chicago & \$1.68 billion & 37 \\
Houston & \$934 million & 33.1 \\
Baltimore & \$536.4 million & 26.4 \\
San Jose & \$449 million & 30 \\
Detroit & \$330 million & 29.9 \\
Atlanta & \$248.5 million & 30.3 \\
Minneapolis & \$163.2 million & 35.8 \\
\hline
\end{tabular}

${ }^{a}$ Not updated since 2017

Source: McCarthy, 2020; Central City Association of Los Angeles, 2020; Levin, 2020

cities, the overall budgets for 2020-2021 were reduced an average of 5.6\% in recognition of the COVID-19 impacts on revenue, but the budgets for police departments rose slightly as a share of overall general fund expenditures, from $13.6 \%$ to $13.7 \%$ (Akinnibi et al., 2021).

San Jose, California, America's $10^{\text {th }}$ largest city, saw similar calls for defunding the police department in the 2020-2021 budget cycle. The police department budget was reduced by $\$ 15$ million, which was reallocated to programs like support for in-home child care providers whose services are suffering from COVID-19 impacts. Mayor Sam Liccardo supported limited reforms, such as the reallocation of $\$ 150,000$ in police wage funds to the Independent Police Auditor's Office to investigate changes to use-of-force policies (Bitters, 2020).

In May 2020 San Jose, California was the site of one of the demonstrations that was part of the nationwide protests following George Floyd's death. According to Chief of Police Eddie Garcia, a day of peaceful protest was followed by days of violence, including attacks on the police deployed to protect the downtown from unrest. The scene was characterized as a "blanket of chaos", and "an insurrection of preplanned violence and complete determination to destroy property that inserted itself in the crowd of lawful demonstrators," according to Garcia (Salonga, 2020). In June, 2020 the police review process was begun, including an audit of the use of police resources (Maguire, 2021).

In August 2020, when the city council returned from its summer recess, the issue of police defunding was added to the agenda by the mayor and several council members. On August 18, 2020, the City Council discussed new initiatives from the mayor and council members contained in memos, collectively entitled, "Actions Related to Police Reform, Reimagining Police, and Strengthening the Investigative Authority of The Office of The Independent Police Auditor," that included a "reimagining public safety" process (City of San Jose, 2020c). A second memorandum specifically called for "reimagine public safety response, such as by supplanting SJPD response 
to many non-criminal matters with a civilian response," and called for the city auditor to expand "the scope of the existing staffing audit to incorporate an analysis of the 1.2 million calls for police service, police budgetary allocations, and progress toward civilianization" (City of San Jose, 2020d).

By March 2021 the city auditor's report on police overtime showed that lack of police staffing was driving up police overtime costs, along with growing varieties of demands for services (Rios, 2021). The City Manager's Office described a "reimagining community safety" process as examining police interventions with social issues that are non-criminal, and recommending "practices to help improve community/police relations" including "taking ongoing community feedback" (Maguire, 2021, p. 4). A broadly based community advisory committee is collaborating with city staff on developing the "shared vision of the future of police work" (Maguire, 2021, p. 5).

\section{Theoretical Perspective of Police Budgets}

Most literature on budgeting focuses on the federal level of budgeting (Morgan et al., 2014; Wildavsky, 1984). The research at this level indicates that budgeting decisions are reliant on interest-based requirements and are a compromise between interest groups and elites in political power (Wildavsky, 1984). However, police budgets are at the local level of government, and the budgetary process runs differently at that level. At the local government level, polity-based requirements encourage collaboration between legislative and executive staff and citizens, and ideally should follow a balanced budgetary process that combines responsive, competent, accessible, and civic governance (Morgan et al., 2014). This combines deliberative governance, with citizen legislatures, systematic planning that balances effectiveness with efficiency, equal treatment of and due process for minorities established through accountability, and citizen participation and co-production of governmental services. However, as Rosenbloom (2009, p. 286) points out, "the mixture of managerial, political, and legal dimensions of public budgeting and finance makes it difficult to develop a budgetary process that is coherent and satisfies all governmental needs." There is wide variation among the 89,500 local government jurisdictions in terms of how they raise and spend revenues. Therefore, there are several approaches, not just one, to how local governments develop and execute their budgets. Rosenbloom (2009) provides three approaches: the managerial, political, and legal approaches.

The managerial approach seeks to promote efficiency, economy, and effectiveness. This approach, especially with the rise of New Public Management, emphasizes performance management. In terms of budgeting, the managerial approach is exhibited in rational budgeting systems. One example is performance budgeting, which focuses on the activities of individual organizational units and how those activities achieve the desired outcomes. Another example is program budgeting, which focuses not on the activities of a single organization, but on the overall purpose of those activities that overlap several organizational units. Such systems emphasize the need to build cost-effectiveness considerations into the budget 
formulations. Ideally, under this approach the projected cost vs. benefit, or return on investment (ROI), helps determine how to allocate funds among the multitude of governmental functions and at what levels. The main criticism of the managerial approach is that it places the locus of control with the executive, which has a near monopoly on the necessary information, sets the goals, and is responsible for measuring performance with which to make budgetary decisions. This, in turn, makes accountability difficult, because the decision-making power resides with the executive and not with the legislature, whose members are more closely tied to the citizens.

Whereas the managerial approach highlights the administrative imperatives of budgeting, the political approach emphasizes several other concerns such as "representation, consensus and coalition building, and the locus of power in allocating funds" (Rosenbloom, 2009, p. 297). Unlike performance and program budgeting and the concern about an ROI that is exemplified in the managerial approach, the main process in the political approach is incrementalism. Incrementalism treats the last period's budget levels as the base level, or starting point for the new period. Because incrementalism avoids any analysis of comprehensive goals, it allows for the participation of multiple stakeholders and facilitates coalition building and consensus decision making. This allows for widespread representation of multiple interest groups from the community. The coalitions are held together because incremental budgeting allows for all parties to have a piece of the funding. Another major feature of incremental budgeting is that, unlike the managerial approach which favors the executive, it allows the decision for resource allocation to remain with the legislature, thus keeping the decision authority more closely connected to the citizenry, from whom the revenue is raised. The main criticism of the political approach is that incrementalism makes it difficult, if not impossible, to administer properly because a clear identification of objectives and priorities is systematically avoided. In an effort to appease all parties, goals are intentionally unclear and sometimes contradictory, making the management of agencies' budgets and programs difficult.

The legal approach to budgeting in public administration is less conspicuous than the managerial or political approach. Nonetheless, the judiciary has grown in influence over the public budgetary process over the last 40 years. This approach seeks to protect constitutional integrity and the rights of individuals, assure equal protection under the law, and promote procedural fairness and equity (Rosenbloom, 2009, pg. 300). Maximizing these values costs money. However, two unique aspects of the judicial approach make it stand out from the managerial and political approaches. The first is that judicial decrees do not seek to force the government to spend money on functions that promote these values, rather they decree that any government function, for example public housing, health, law enforcement or prisons, must not violate individual rights in the process of executing government functions. The second is that the cost to reform policies, agencies, or institutions to ensure that individual rights are protected are not considered nor a concern of the judiciary. The lack of integration with either the managerial or political aspects of budgeting leads to the major criticism of the judicial approach.

Many local government public managers may be frustrated by the "unfundedmandate" nature of the judicial approach which seeks to prevent attempts to deny 
some groups representation. In this situation, public managers may find incrementalism in the political approach more useful at maintaining consensus, but still frustrating because of the lack of clear objectives. Therefore, public managers may prefer the rational approaches to budgeting afforded by the managerial approach, since many of the functions at the local level of governments seem more suited to managerial approaches in public budgeting. This may lead to managerial manipulations to both balance the budget/political agendas, and accomplish their missions.

The literature on police budgeting provides several examples of managerial options. One option is to assign a price for police service and levy the cost on the individual users of that service, such as citizens who call on the police, or suspected criminals that police respond to (Edmonds \& McCready, 1994). While several police departments in Canada have such a structure, researchers in the U.S. have found that this approach is politically unfeasible since it invariably levies a cost on a group that has the political power to change it, or incurs a cost on a marginal group causing the courts to step in and modify it.

Another option is to use norm-based costing, instead of activities-based costing, in allocation of scarce resources for police services (Ryan, 2001). Whereas activity-based costing methods try to balance activities with resources within units with routinized patterns of activities, normed-based costing recognizes that police have highly non-routinized and often reactive activities, and thus it looks to normalize the balance of resources and activities between units. While theoretically interesting, the main concern with this approach is that it relies heavily on the assumption of a strictly linear relationship between activities and resources. Thus, the political conditions surrounding budgeting are held constant, which does not seem realistic given the politically contentious nature of police work.

Nonetheless, the literature on police budgeting does reveal normatively acceptable budgeting strategies. These include "using crime and workload data judiciously; capitalizing on sensational crime incidents; effectively getting the message out; carefully mobilizing interest groups; strategic planning; playing the federal grants game; working closely with the chief executive and elected officials; and involving all departmental staff levels in budgeting" (Coe \& Wiesel, 2001, p. 718). Still the increasing and expanding scope of activities that fall under the purview of police work, the attrition of the total number of sworn officers, and the reduction of police budget, require police departments to implement a variety of variable cost strategies to meet demand and manage the lack of personnel and funding (Wilson \& Heinonen, 2011).

One of those strategies entails the management of variable costs such as overtime, temporary employees, or re-work, which constitutes budgetary slack (Davila \& Wouters, 2005). Organizations will employ techniques to capitalize on budgetary slack when they reach or are close to reaching capacity to accomplish their mission or goals. Utilizing budgetary slack to overcome shortfalls in capacity has often been viewed as inefficient and lacking effectiveness in budgetary implementation (Dunk \& Nouri, 1998; Kamin \& Ronen, 1981; Granlund \& Lukka, 1998; Merchant, 1985; Walker \& Johnson, 1999; Webb, 2002). In fact, the utilization of budget slack is assumed to cause budgetary dysfunction, or considered unethical (Douglas \& Wier, 2000) and should be limited (Dunk, 1995; Fisher et al., 2000, 2002; 
Nouri, 1994; Young, 1985). Utilizing budgetary activities, such as overtime, or temporary workers, is assumed to isolate organizational personnel from the purpose of the activity as resourced in the budgets, reduce the impact of managers' efforts, and cause inefficient use of the budgeted resources (Davila \& Wouters, 2005).

Nonetheless, police departments continue to rely on such variable cost, or budgetary slack opportunities such as overtime. For example, the US National Institute of Justice reported in 1998 that it is not unusual for police service to spend up to $6 \%$ of its budget on overtime (Taylor Griffiths et al., 2015). Given the expanded nature of police work in the twenty-first century, it is not unreasonable to estimate that that amount has doubled. Furthermore, research indicates that there are positive effects in utilizing budgetary slack resources such as overtime. For example, budgetary slack gives managers more control and discretion to accomplish multiple and competing goals, while allowing them to deal with adverse exogenous factors such as calls for reduced budgets by the public (Davila \& Wouters, 2005; Lillis, 2002; Merchant \& Manzoni, 1989). The extant literature on police budgets that point to the use of overtime and other budget slack, or variable costs management techniques, to manage complex and constrained budgetary environments leads to this article's purpose and research questions.

\section{Statement of Purpose and Research Questions}

The researchers wanted to understand the impact of budgeting police overtime funding to provide on-going services. They investigated the various uses of overtime funding to evaluate the benefits of paying overtime against other financial or organizational options, such as hiring more staff. This research was structured using the San Jose City Auditor's study of the SJPD's overtime budget (Rios, 2021) to investigate the following questions:

How is police overtime funding being used to deliver police services?

Is the use of overtime the most efficient method of providing police services?

\section{Research Approach}

The researchers engaged in program evaluation as participant observers. One researcher has experience as the budget officer for the Irvine Police Department, and as director of the San Jose Metropolitan Medical Task Force and later the San Jose Urban Area Security Initiative, entailing the management of federal funds for community safety and counter-terrorism activities. They defined the problem as inadequate funding for all demanded police activities. The solution developed by many cities is to use overtime funding to cover public safety activities when they are demanded, which is implemented annually when the public safety budget is developed. The evaluation uses a case study approach, focusing on the City of San Jose's budget and its police department programming and service demands. The definition 
Table 2 San Jose Population Demographics

\begin{tabular}{ll}
\hline Demographic & Factor \\
\hline Asian & $35.9 \%$ \\
Hispanic or Latino & $31.6 \%$ \\
White & $25.7 \%$ \\
Two or more races & $5.3 \%$ \\
Black & $3 \%$ \\
American Indian & $0.6 \%$ \\
Pacific Islander & $0.5 \%$ \\
Foreign born & $39 \%$ \\
Speaks other than English at home & $57 \%$ \\
Median household income & $\$ 109,593$ \\
Living in poverty & $8.9 \%$ \\
Median home value & $\$ 864,600$ \\
Average monthly apartment rent & $\$ 2,107$ \\
\hline
\end{tabular}

Source: US Census Bureau 2019

of a case study is an "empirical inquiry that investigates a contemporary phenomenon in depth and within its real-life context." (Yin's, 2009, p.14).

\section{Research Results}

\section{Characteristics of San Jose}

In 2019, the last year for which US Census data is available for San Jose, the SJPD was serving an ethnically diverse city with 1,021,795 residents, as demonstrated in Table 2.

\section{General Fund Revenue Limitations}

Public safety services in California are paid for from the General Fund of each municipality. In 1978 California voters passed Proposition 13, which "set property tax rates at 1 percent, limit annual increases to 2 percent or inflation (whichever is lower), and only reassess a property's taxable value after a sale. Additionally, it would establish supermajority requirements for state and local tax increases" (Rueben \& Auxier, 2018, n.p.). In the more than 40 years since its approval by the voters, this California constitutional amendment has significantly limited the ability of local governments to raise revenue from local property taxes, which have traditionally supported local government services, like police departments. This, in turn, shifted power from the local governments to the state, with state sales taxes - only $1 \%$ of which is rebated to the jurisdiction where the sale occurred-and income taxes supporting public services at a higher proportion than local property 
taxes (Citrin, 2009). In some cases, local governments were able to fund public services through parcel taxes and fee-for-service (Coleman, 2016), but General Fund Revenue from real estate taxes to support basic government services like public safety have not kept up with expenses. Increases in public employee labor contract costs alone have outpaced the growth rate of the Proposition 13 limitations of $2 \%$ per year (Citrin, 2009).

In 2016 the League of California Cities determined that real estate property taxes only accounted for $14 \%$ of the average city's revenues, with another $7 \%$ from sales tax, $43 \%$ from fees, and $9 \%$ from state and federal transfers for specified purposes. Thus, General Fund supported activities like public safety rely on a very small percentage of the city's revenue stream. Only $36 \%$ of a city's revenues are unrestricted, meaning that they can be budgeted for municipal activities as determined by the city council, including public safety (Coleman, 2016). For 2020-2021 the City of San Jose realized $\$ 370,500,000$ in property tax revenue (35\%), $\$ 242,500,000$ in sales tax revenue $(23 \%)$ and $\$ 95,800,000$ in utility fees $(9 \%)$ of the $\$ 1,042,445,727$ general fund budget, the three largest revenue sources (City of San Jose 2020-2021 Adopted Operating Budget, 2020a).

\section{General Fund Expenses for Police Department Services}

In fiscal year 2020-2021, the budget for the SJPD was \$471,530,192 (San Jose, 2020b), with about $10 \%$ of the budget allocated for overtime (City of San Jose Auditor's Office, 2021).

Overtime falls into two categories: mandatory and discretionary. Mandatory overtime is used when there is a shortage of sworn officers, and officers are required to work extra hours to fill vacant patrol positions to maintain required minimum staffing for each shift. Court time and hold overs for calls for service at the end of shift or arrestee processing are also mandatory. Discretionary overtime is initiated by officers who need more time for report writing, training and case follow-up (Rios, 2021).

Overtime is paid for in two ways: extra pay in the current paycheck, or tcompensatory time which is "banked" to a maximum of $480 \mathrm{~h}$ per individual. Comp time may be used later for time off, or they may be kept and paid out at the hourly rate at the time of separation. Hours exceeding 480 are paid when earned. While "banking" pushes the cost of overtime off to another fiscal year, it raises the cost, as there are salary increase in each new contract, and the member may have promoted to a higher rank by payout. In 2007-2008 total comp time payout was $\$ 260,000$ (Rios, 2021). In 2019-2020 there was \$16 million paid in excess compensatory time payouts, while there was over \$21 million "banked," with "449 individuals [at the] maximum compensatory time accrual limit" (Rios, 2021, p. 57).

In 2019-2020 there were 1,716 full time equivalent (FTE) employees in the SJPD budget, of whom 1,151 are sworn officer positions, and 64 are non-sworn community service officers (City of San Jose, 2020b). Table 3 demonstrates the areas of budgeted services.

Table 4 defines the duties of the various sections of the SJPD. 
Table 3 San Jose Police Department Budget, 2020-2021

\begin{tabular}{ll}
\hline Strategic Support- Other & $\$ 15,837,057$ \\
Strategic Support- Public Safety & $\$ 60,018,841$ \\
Crime Prevention \&Community Education & $\$ 7,092,256$ \\
Investigative Services & $\$ 88,465,656$ \\
Regulatory Services & $\$ 4,783,504$ \\
Calls For Service And Patrol & $\$ 295,352,878$ \\
Total SJPD 2020-2021 Budget & $\$ 471,530,192$ \\
\hline
\end{tabular}

Source: City of San Jose, 2020b

Table 4 San Jose Police Department Core Services

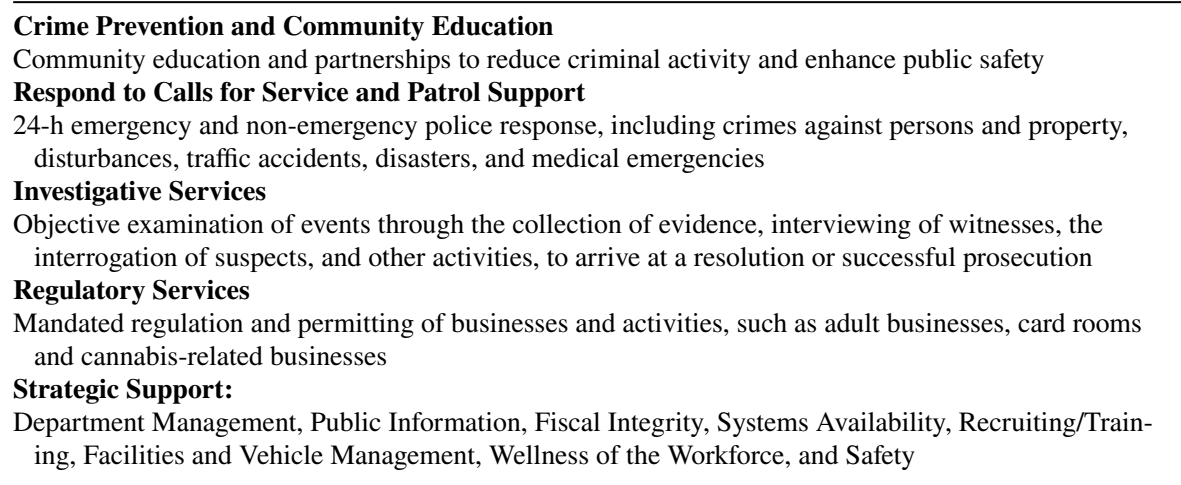

Source: City of San Jose, 2020b

Over $45 \%$ of the City of San Jose's General Fund budget is spent for police services. Salaries and benefits account for \$395,982,318 (84\%) of the Police Department's budget, while $\$ 27,110,896$ (6\%) is for overtime expenses. Coleman (2016) noted that the largest categories of budget increase for cities are in the benefits category-pension costs and health care costs for retired workers. This has made using officers on overtime more attractive than hiring additional officers, since overtime us not pensionable. Officials have also noted the difficulty of hiring police officers in the city's high housing cost environment (Lopez, 2019).

Pension expense has been a fiscal challenge, most notably during the great recession. In June, 2012 San Jose voters put in place new rules for city worker pensions to lower the costs to the city, and the benefits to new employees. However, San Jose city employees are not eligible for Social Security, so their pensions are their only source of retirement income. Thus, the unions sued the city, noting how difficult it was to recruit public safety personnel because neighboring jurisdictions had better salaries and benefits. By 2016 the city's pension liability stood at \$3 billion. In November, 2016 the San 
Jose City Council altered the pension reforms to satisfy the lawsuit requirements, while still saving the city $\$ 1.7$ billion over ten years. Public votes on pension enhancements and a new benefit package for new employees were the hallmarks of the landmark reforms, including older retirement ages and a lower ceiling on maximum percentage of salary that a pension can represent (Ring, 2017).

\section{Hiring Alone is not the Answer}

Some SJPD positions cannot be filled efficiently by hiring new fulltime employees, while other activities consume overtime on unpredictable bases. While some uses of police overtime might be able to be programmed into regular work calendars, a lack of staffing makes that problematic at present.

\section{Training}

California law enforcement officers are required by the Peace Officers Standards and Training organization (POST) to take specific courses and have specific numbers of hours doing practical exercises. For example, officers have to periodically prove their proficiency with their equipment, including time at the shooting range. They must regularly participate in the Attorney General's Updates to be aware of evolving case law that controls their arrest powers and interactions with the public. Patrol officers are responsible for responding to calls for service in specified areas of the city, so they cannot be absent from their patrol areas to engage in training. This means that overtime has to be provided to cover the number of hours required by POST for each San Jose Police officer.

In some departments there are adequate resources to have fulltime officers who are "floaters" who are able to cover beats for officers who are in training so that no one is on overtime (Rios, 2021). "Lower numbers of sworn staffing mean that officers must complete training requirements on overtime outside of their regular shifts to maintain minimum levels of field patrol staffing" (Rios, 2021, p.65.)

\section{Young and Inexperienced Department}

During the economic downturn the city changed the pension rules for public safety employees, including raising the contribution that public safety personnel had to make to their retirement accounts, resulting in a $10 \%$ cut in take-home pay for most officers, along with a reduction in pension benefits (Rios, 2021). As a result, many officers left the department. In 2016-2017 there were 1,107 budgeted sworn positions but 200 vacancies, leaving only 900 sworn personnel in 2017 (Rios, 2021, Exhibit 9, p. 25).

This created a gap in department members' service time (Rios, 2021). People who were relatively close to retirement, were in specialty assignments, or who had recently promoted generally stayed in San Jose, while people who had passed 
probation and completed their training generally left. That event was about ten years ago, so today there are few people with 10 to 15 years of service. These would normally be the sergeants and lieutenants, the field training officers and the line leaders. The mid-range people who stayed promoted more quickly because of the gap in tenure, so they are now captains and more senior leaders, or in advanced specialty roles, meaning that many of the street patrol officers lack experience and are still perfecting their skills. The audit of the Police Department found that the "Department's police force is overall less experienced than it was ten years ago" (Rios, 2021, p. 4), leading to a notable increase in overtime for report writing and follow-up activities.

Many calls for service responses require documentation through a police report. Experienced officers may know exactly what facts to collect at the scene, and know how to create the required report. Younger, less experienced officers may need more time to create the report, including more follow-up time to assemble additional information, meaning that a less experienced officer might need overtime to complete the task (Rios, 2021). "Report writing and follow-up activities have more than doubled since 2014-2015" (Rios, 2021, p. 64).

\section{Disasters and Emergencies}

It is impossible to budget for disasters and emergencies. In 2020 the SJPD was coping with the COVID-19 pandemic, managing staff heath concerns and community calls for service related to testing site, and later vaccination site, traffic issues. Civil unrest in the summer generated nights of unexpected overtime for law enforcement personnel, including interactions with the public that led to extensive report writing. In the summer of 2020 San Jose also experienced the SCU complex wildland interface fire that threatened the east side of the city, and generated community calls for assistance. None of these overtime events could have been anticipated, and their time and cost impacts were unknown until they actually occurred.

San Jose is in an area with significant natural hazards. There are three active faults in the Santa Clara Valley, two waterways that flood, and six areas with the potential for wildland urban interface fires. There is an international airport, four major freeway systems, three passenger rail lines, a freight rail line and a major regional pipeline in the community, any of which could generate an emergency or disaster without notice (Santa Clara County, 2017). Thus, emergency and disaster related-overtime is unpredictable but probably inevitable.

More recently, perhaps related to the origins of COVID-19, the Asian population has experienced an upsurge of violent crimes against persons. As a result, a special patrol has been established in Japantown and Little Saigon to deter acts of violence. Because the need arose suddenly in the middle of a budget year, the new foot patrol beats have to be covered using overtime (Salonga, 2021). 


\section{Court Time}

Officers are required to be available for court whenever a case that they are involved in will be tried, generating mandatory overtime (Rios, 2021). While many arrests are resolved outside of court, others go to trial, and the time off patrol may be difficult to estimate. Thus, someone has to cover the patrol duties of the officer who is in the courtroom. While this is often just part of a shift, in some cases the officer may be in court for multiple days (F. Edwards, personal communication, May 25, 2021).

\section{On-Going Specialty Programs}

The SJPD provides patrol services at the Mineta San Jose International Airport, which is an enterprise fund activity, meaning that it must raise its own costs from user fees. In 2011-2012, 41 full-time sworn positions were removed from the police budget, so airport policing is paid for with overtime funds at time and a half, but with no new benefits required.

Similarly, new foot patrol beats in support of community policing were added in 2013-2014, but continue to be funded through overtime due to a lack of fulltime sworn personnel.

"Paid car" assignments - specialty activities- are also paid with overtime funds. They include truancy abatement, downtown services, entertainment zone patrols and hazardous escorts. Sometimes these assignments are driven by changes in crime patterns, while other assignments are episodic and unpredictable. Overtime is used for these activities to allow command staff to "balance staffing and workload assignments" (Rios, 2021, p. 66).

\section{Discussion}

Under normal circumstance, variable cost management, such as managing by overtime, would be viewed as inefficient and counter to the principals of good fiscal stewardship. However, the results above indicate that local police organizations, the SJPD in particular, do not operate under normal circumstances. In addition to all of the external factors at play in shaping the mission and operations of the SJPD, two main issues set the context for understanding their use of overtime as a budgetary management tool. The first issue is the fiscal impact of the wave of calls for police reform because of the events surrounding the death of George Floyd. The second is the diverse population demographic that composes the citizenry of San Jose, for whom SJPD officers are responsible for providing services.

The murder of George Floyd resulted nationally in persistent calls for the defunding, and in some cases abolishment, of many metropolitan police departments, a political consequence of this event. Questions about the mission, focus, and goals of police departments were debated in the media and city council meetings. This heightened the turbulence and uncertainty that police departments like SJPD were 
already experiencing, and established the need for them to find alternative ways of managing their community services with reduced resources, thus making management by overtime an appealing, if cumbersome, budgetary tool of choice.

The diverse populations of Hispanics and Asians suggests that budgetary management in SJPD has less to do with white-black race relations, and more to do with maintaining equitable services for all populations represented in this Bay Area city, as exemplified by the new foot patrols created in response to anti-Asian violence. Decisions to reduce the police budget, therefore, align with Rosenbloom's political approach, in that they respond to community demands while seeking to spread the resources out to the many groups that compose the population of San Jose. Therefore, with the reduction in the ability to hire and train new and diverse police officers, the SJPD has found that it needs to rely on slack resources to meet its continued requirements to serve the evolving needs of the diverse community of San Jose with current staffing levels. One useful tool has been the use of overtime funds to help SJPD meet on-going patrol needs, as well as unforeseen and contingent operating requirements.

Nationwide, calls for police reform will continue. Budgetary changes will inevitably follow a combination of the managerial, political and judicial approaches articulated by Rosenbloom. The use of overtime as a management tool, as illustrated by the case study presented in this article, demonstrates that that is one tool that police departments may have to rely on for the near term, while the mission of police departments is redefined nationally.

\section{Declarations}

Ethical Statement There are no human subjects for this research. All data sources are public agency documents or publicly available sources. This research qualified for an Exclusion under the San Jose State University Institutional Research Board.

Conflict of Interest We have no conflict of interest.

Informed Consent N/A.

\section{References}

Akinnibi, F., Holder, S., \& Cannon, C. (2021). Cities say they want to defund the police. Their Budgets Say Otherwise. Bloomberg City Lab, January 12. https:/www.bloomberg.com/graphics/2021-citybudget-police-funding/

Birkand, T. (1997). After disaster: agenda setting, public policy and focusing events. Georgetown University Press.

Bitters, J. (2020). Hundreds ask San Jose lawmakers to defund police ahead of budget vote. San Jose Spotlight, June 16. https://sanjosespotlight.com/hundreds-ask-san-jose-lawma kers-to-defund-police-ahead-of-budget-vote/

Central City Association of Los Angeles. (2020). CCA Reflects: LA City Budget 101. CCA News, June 24. https://www.ccala.org/news/2020/06/24/cca-reflects/cca-reflects-la-city-budget-101/ 
Citrin, J. (2009). Proposition 13 and the Transformation of California Government. The California Journal of Politics \& Policy, 1(1), 1-9.

City of San Jose. (2020a). 2020-2021 Adopted Operating Budget. Total City Source and Use of Funds. https://www.sanjoseca.gov/home/showpublisheddocument/66365/637396666649200000

City of San Jose. (2020b). 2020-2021 Annual Budget, Police Department. https://www.sanjoseca.gov/ home/showpublisheddocument/66337/637469369067670000

City of San Jose. (2020c). Memorandum: actions related to police reform, reimagining police, and strengthening the investigative authority of the Office of the Independent Police Auditor: Liccardo, Jones, Diep, Peralez, Carrasco. Agenda Item 4.3. August 18, 2020.

City of San Jose. (2020d). Memorandum: actions related to police reform, reimagining police, and strengthening the investigative authority of the Office of the Independent Police Auditor: Liccardo, Jones, Diep and Carrasco. Agenda Item 4.3. August 18, 2020.

City of Jose Auditor's Office. (2021). Police staffing, expenditures, and workload: staffing: reductions have impacted response times and led to high overtime costs. Report 21-01, March 2021.

Coe, C. K., \& Wiesel, D. L. (2001). Police budgeting: winning strategies. Public Administration Review, 61(6), 718-727. https://doi.org/10.1111/0033-3352.00142

Coleman, M. (2016). A Primer on California City Revenues. League of California Cities.

Davila, T., \& Wouters, M. (2005). Managing budget emphasis through the explicit design of conditional budgetary slack. Accounting, Organizations and Society, 30(7), 587-608. https://doi.org/10.1016/j.aos. 2004.07.002

Douglas, P. C., \& Wier, B. (2000). Integrating ethical dimensions into a model of budgetary slack creation. Journal of Business Ethics, 28, 267-277.

Dunk, A. S. (1995). The joint effects of budgetary slack and task uncertainty on subunit performance. Accounting and Finance, 30(2), 61-75.

Dunk, A. S., \& Nouri, H. (1998). Antecedents of budgetary slack: A literature review and synthesis. Journal of Accounting Literature, 17, 72-96.

Edmonds, D., \& McCready, D. (1994). Costing and pricing of police services. International Journal of Public Sector Management, 7(5), 4-14. http://dx.doi.org.libaccess.sjlibrary.org/10.1108/095135594100674 74

Ferkenhoff, E. (2021). Minneapolis leaders promised big changes in policing after George Floyd's death. Keeping them is taking longer than some hoped. USA Today, March 21. https://www.usatoday.com/ story/news/2021/03/18/defund-police-minneapolis-struggles-reforms-after-george-floyd/4591158001/

Fisher, J., Frederickson, J. R., \& Peffer, S. A. (2000). Budgeting: an experimental investigation of the effects of negotiation. The Accounting Review, 75(1), 93-114.

Fisher, J., Frederickson, J. R., \& Peffer, S. A. (2002). The effect of information asymmetry on negotiated budgets: an empirical investigation. Accounting Organizations and Society, 27, 27-43.

Gordon, T., Auxier, R., \& Baddupalli, A. (2020) COVID-19 has turned much of what we thought we knew about city finances upside down. Tax Vox, September 29, 2020. The Urban Institute and Brookings Institution. https:/www.taxpolicycenter.org/taxvox/covid-19-has-turned-much-what-we-thought-weknew-about-city-finances-upside-down

Granlund, M. and Lukka, A. (1998). It's a small world of management accounting practices. Journal of Management Accounting Research 10, 153-179.

Guess, G. M., \& Farnham, P. G. (2011). Cases in public policy analysis. Washington, DC: Georgetown University Press.

Kamin, J. Y., \& Ronen, J. (1981). Effects of budgetary control design on management decisions: some empirical evidence. Decision Sciences, 12(3), 471-476.

Levin, S. (2020). Movement to defund police gains 'unprecedented' support across US. The Guardian, June 4. https://www.theguardian.com/us-news/2020/jun/04/defund-the-police-us-george-floyd-budgets

Lillis, A. M. (2002). Managing multiple dimensions of manufacturing performance-an exploratory study. Accounting, Organizations and Society, 27, 497-529.

Lopez, N. (2019). Who earned the highest salary in San Jose last year? San Jose Spotlight, March 29. https:// sanjosespotlight.com/who-earned-the-highest-salary-in-san-jose-last-year/

Maguire. J. (2021). Memorandum: police reforms work plan and reimagining community safety update. City of San Jose, March 17 2021. https://www.sanjoseca.gov/home/showpublisheddocument/70452/63751 585590170000

Manskar, N. (2020). Riots following George Floyd's death may cost insurance companies up to \$2B. New York Post, September 16. https://nypost.com/2020/09/16/riots-follo wing-george-floyds-death-could-cost-up-to-2b/ 
McCarthy, N. (2020). How much do U.S. cities spend on policing? Statista, June 12. https://www.statista. com/chart/10593/how-much-do-us-cities-spend-on-policing/

Merchant, K. A. (1985). Budgeting and the propensity to create budget slack. Accounting, Organizations and Society, 10, 201-210.

Merchant, K. A., \& Manzoni, J. F. (1989). The achievability of budget targets in profit centers: a field study. The Accounting Review, 64, 539-558.

Morgan, D., Robinson, K. S., Strachota, D., \& Hough, J. A. (2014). Budgeting for local governments and communities (1st ed.). New York: Routledge.

Mummolo, J. (2018). Militarization fails to enhance police safety or reduce crime but may harm police reputation. Proceedings of the National Academy of Sciences of the United States of America. September 11. https://www.pnas.org/content/115/37/9181

Nouri, H. (1994). Using organizational commitment and job involvement to predict budgetary slack: a research note. Accounting, Organizations and Society, 19(3), 289-295.

Perez, J. (2018). Police response to mental health-related calls for service in the City of Watsonville. Final Project, MPA Program. San Jose State University ScholarWorks. Spring 5-2018. https://scholarworks. sjsu.edu/etd_projects/592/

Ring, E. (2017). Pension Reform - The San Jose Model. California Policy Center. September 6. https://calif orniapolicycenter.org/pension-reform-san-jose-model/

Rios, J. (2021). Police staffing, expenditures and workload: staffing reductions have impacted response times and led to high overtime costs. Office of the City Auditor, Report 21-01. March 5. https://www.sanjo seca.gov/home/showpublisheddocument?id=70064

Rosenbloom, D. H. (2009). Public Administration: understanding management, politics, and law in the public sector, 7th edn. Boston. http://hdl.handle.net/2027/inu.30000124721535

Rosewicz, B., Theal, J., \& Fall, A. (2021). Pandemic drives historic state tax revenue drop. The Pew Trust, February 17. https://www.pewtrusts.org/en/research-and-analysis/articles/2021/02/17/pandemic-driveshistoric-state-tax-revenue-drop

Rueben, K., \& Auxier, R. (2018). Lessons learned 40 years after a monumental tax law. The Hill, June 5. https://thehill.com/opinion/finance/390779-lessons-learned-40-years-after-a-monumental-tax-law

Ryan, M. J. (2001). Variance analysis, normed costs and public safety organizations. Applied Economics, 33(6), 755-762. https://doi.org/10.1080/00036840121862

Salonga, R. (2020). San Jose police, city defend use of force at protests: 'I stepped into a war zone'. Mercury News, June 4, 2020. https://www.mercurynews.com/2020/06/04/san-jose-police-city-defend-use-offorce-at-protests-i-stepped-into-a-war-zone/

Salonga R (2021) San Jose's Little Saigon, Japantown see increased police foot-patrol presence. Mercury News, April 3, 2021. https://www.mercurynews.com/2021/04/03/san-joses-little-saigon-japantown-seeincreased-police-foot-patrol-presence/

Santa Clara County (2017) Santa Clara County Operational Area Hazard Mitigation Plan. https://emerg encymanagement.sccgov.org/sites/g/files/exjcpb261/files/For\%20Partners/Local-Hazard-MitigationPlan-LHMP-Vol-1.pdf

Smith R.(2020). Insurance costs for George Floyd riots will be most expensive in history. Insurance Business. September 18. https://www.insurancebusinessmag.com/us/news/breaking-news/insurance-costs-forgeorge-floyd-riots-will-be-most-expensive-in-history-233905.aspx\#: :text=While\%20the\%20protests\% 2C\%20which\%20occurred,in\%20claims\%2C\%20according\%20to\%20Axios

Stockman, F., \& Eligon, J. (2020). Cities ask if it's time to defund police and 'reimagine' public safety. New York Times, June 5, 2020. P. A15. https://www.nytimes.com/2020/06/05/us/defund-police-floyd-prote sts.html

Taylor, D. B. (2021a). A timeline of the coronavirus pandemic. The New York Times, March 17, 2021. https://www.nytimes.com/article/coronavirus-timeline.html

Taylor, D. B. (2021b). George Floyd protests: a timeline. New York Times, March 28. https://www.nytimes. com/article/george-floyd-protests-timeline.html?auth=login-email\&login=email

Taylor Griffiths, C., Pollard, N., \& Stamatakis, T. (2015). Assessing the effectiveness and efficiency of a police service: The analytics of operational reviews. Police Practice \& Research, 16(2), 175-187. https://doi.org/10.1080/15614263.2014.972621

US Census Bureau. (2019). Quick Facts: San Jose city, California. https://www.census.gov/quickfacts/fact/ table/sanjosecitycalifornia/PST045219

Walker, K. B., \& Johnson, E. N. (1999). The effects of a budget based incentive compensation scheme on the budgeting behavior of managers and subordinates. Journal of Management Accounting Research, 11, $1-28$. 
Webb, R. A. (2002). The impact of reputation and variance investigations on the creation of budget slack. Accounting, Organizations and Society, 27, 361-378.

Wildavsky, A. B. (1984). The politics of the budgetary process. Boston: Little, Brown.

Wilson, J. M., \& Heinonen, J. A. (2011). Advancing a police science: implications from a National Survey of Police Staffing. Police Quarterly, 14(3), 277-297. https://doi.org/10.1177/1098611111414001

Yin, R. K. (2009). Case study research: design and methods (4th ed.). Thousand Oaks: Sage.

Young, M. (1985). Participative budgeting: the effects of risk aversion and asymmetric information on budgetary slack. Journal of Accounting Research, 23(2), 829-842.

Publisher's Note Springer Nature remains neutral with regard to jurisdictional claims in published maps and institutional affiliations. 